\title{
Antimicrobial and antioxidant properties of methanol extract, fractions and compounds from the stem bark of Entada abyssinica Stend ex A. Satabie
}

Gerald N Teke ${ }^{1}$, Paul K Lunga ${ }^{1}$, Hippolyte K Wabo ${ }^{2}$, Jules-Roger Kuiate ${ }^{1 *}$, Gerard Vilarem³ ${ }^{3}$ Geraldine Giacinti ${ }^{3}$, Haruhisa Kikuchi ${ }^{4}$ and Yoshiteru Oshima ${ }^{4}$

\begin{abstract}
Background: The aim of this study was to evaluate the antimicrobial and antioxidant activities of the methanol extract, fractions and isolated compounds from Entada abyssinica stem bark, plant used traditionally against gastrointestinal infections.

Methods: The methanol extract of E. abyssinica stem bark was pre-dissolved in a mixture of methanol and water, and then partitioned between $n$-hexane, ethyl acetate and $n$-butanol. The ethyl acetate portion was fractionated by column chromatography and the structures of isolated compounds elucidated by analysis of spectroscopic data and comparison with literature data. Antimicrobial activity was assayed by broth microdilution techniques on bacteria and yeasts. The antioxidant activity was determined by DPPH radical scavenging method.

Results: Four known compounds [(5S,6R,8aR)-5-(carboxymethyl)-3,4,4a,5,6,7,8,8a-octahydro-5,6,8atrimethylnaphthalenecarboxylic acid (1), methyl 3,4,5-trihydroxybenzoate (2), benzene-1,2,3-triol (3) and 2,3dihydroxypropyltriacontanoate (4)] were isolated. Compared to the methanol extract, fractionation increased the antibacterial activities of the $n$-hexane and ethyl acetate fractions, while the antifungal activities increased in ethyl acetate, $n$-butanol and aqueous residue fractions. The isolated compounds were generally more active on bacteria $(9.7$ to $156.2 \mu \mathrm{g} / \mathrm{ml}$ ) than yeasts $(78.1$ to $312.5 \mu \mathrm{g} / \mathrm{ml}$ ). Apart from compound $\mathbf{1}$, the three others displayed DPPH' scavenging activity (RSa), with RSa 50 values of 1.45 and $1.60 \mu \mathrm{g} / \mathrm{ml}$.
\end{abstract}

Conclusion: The results obtained from this study support the ethnomedicinal use of $E$. abyssinica in the treatment of gastrointestinal infections and the isolated compounds could be useful in the standardisation of antimicrobial phytomedicine from this plant.

\section{Background}

Exploring the healing power of plants is an ancient concept. For many centuries people have been trying to alleviate and treat diseases with different plant extracts and formulations [1]. The interest in plants with antimicrobial properties has been revived because of current problems associated with the use of antibiotics [2]. Many microbial infections lead to the production of

\footnotetext{
* Correspondence: jrkuiate@yahoo.com

'Laboratory of Microbiology and Antimicrobial Substances, Faculty of

Science, University of Dschang, P.O. Box 67 Dschang, Cameroon

Full list of author information is available at the end of the article
}

highly reactive molecules from the metabolism of oxygen that can cause extensive damage to cells and tissues [3]. The fact that microorganisms nowadays tend to develop resistance towards drugs, coupled to the undesirable side effects of certain antibiotics offer considerable potentials for the development of new effective antimicrobial and antioxidant agents; medicinal plants are a prolific source.

Entada abyssinica (Mimosaceae) is an understorey forest deciduous tree, 3-15 m high, with a flat spreading crown. It is widespread in central and eastern tropical Africa [4]. It has a grey stem bark, glabrous leaves and 
creamy white flowers [5]. A decoction of the stem bark is locally used in the treatment of coughs, rheumatic and abdominal pains, and diarrhoea while the root or leaf decoction is used in the treatment of fever and to prevent miscarriage [5]. The fresh roots are used against gonorrhoea [6].

Some biological activities of Entada abyssinica have been reported. The leaves are highly active against Semliki forest virus [7]. Weak antibacterial activities of the methanol extract of E. abyssinica stem bark has been reported by Fabry et al. [8]. A number of biologically active compounds have been isolated from E. abyssinica including a diastereoisomer of the clerodane type diterpene, kolavenol [9], flavonoids and phytosterol glycosides [10] and kolavic acid derivatives [11].

However, to the best of our knowledge, no information on its free radical scavenging activities is available. This study was therefore designed to evaluate the possible beneficial antimicrobial and antioxidant potencies of the methanol extract, fractions and compounds from this plant.

\section{Methods}

\section{Plant material, extraction and phytochemical screening}

The stem bark of E. abyssinica was collected in May 2007 in Menoua Division, West Cameroon. Botanical identification was done at the Cameroon National Herbarium in Yaounde by Mr Tadjouteu Fulbert, where a voucher specimen was kept under the reference number 44732/ HNC. The stem bark was cut into pieces, air-dried under shade and ground into powder using an electric grinder. A mass of $375 \mathrm{~g}$ of powder was exhaustively extracted with $1 \mathrm{l}$ of methanol. After filtration, the solvent was evaporated under reduced pressure in a rotary evaporator at $45^{\circ} \mathrm{C}$ to afford the methanol extract $(47.50 \mathrm{~g})$. An amount of $32.50 \mathrm{~g}$ of this extract was pre-dissolved in $100 \mathrm{ml}$ of a mixture of methanol and water (1:9) and then $400 \mathrm{ml}$ of $n$-hexane was added and shaken vigorously. After about $30 \mathrm{~min}$, the $n$-hexane phase was collected and the process repeated thrice. Methanol was then evaporated from the polar phase and the aqueous residue treated sequentially with ethyl acetate and $n$-butanol. The $n$-hexane, ethyl acetate and $n$-butanol were evaporated under reduced pressure in rotary evaporator to afford 4.64, 15.78 and $2.63 \mathrm{~g}$ of fractions respectively. The aqueous residue $(9.44 \mathrm{~g})$ was obtained after drying the residual portion in the oven at $40^{\circ} \mathrm{C}$ for $48 \mathrm{~h}$. The methanol extract and fractions were subjected to phytochemical screening using standard procedures [12].

\section{Fractionation and isolation}

A quantity of $10.5 \mathrm{~g}$ of the ethyl acetate fraction was subjected to silica gel $60(0.20-0.500 \mathrm{~mm})$ flash chromatography and eluted with mixtures of $n$-hexane (Hex) and ethyl acetate (EtOAc) of increasing polarity $(0-100 \%)$ to yield a total of 9 fractions of $200 \mathrm{ml}$ each. These fractions were combined on the basis of TLC profiles into four major fractions: F1 [4.77 g, Hex/ EtOAc (100:0), (80:20), (70:30)], F2 [2.48 g, Hex/EtOAc (60:40), (50:50)], F3 [1.56 g, Hex/EtOAc (40:60)] and F4 [0.63 g, Hex/EtOAc (30:70), (20:80), (0:100)]. Fraction F1 was further dissolved in a mixture of Hex and EtOAc (60:40) and a whitish compound precipitated. It was filtered and rinsed with EtOAc to afford compound $1(100 \mathrm{mg})$. The filtrate $(4.5 \mathrm{~g})$ was subjected to further silica gel column chromatography $(0.063-0.200 \mathrm{~mm})$ to afford compound $2(113 \mathrm{mg})$. Fraction F3 afforded compound $3(108 \mathrm{mg})$ as a yellowish powder from the mixture Hex/EtOAc $(60: 40)$. Fraction F4 was further subjected to column chromatography $(0.063-0.200 \mathrm{~mm})$ purification using Hex and EtOAc (40:60) to afford compound 4 (54 mg).

\section{Chemical analysis}

The $n$-hexane fraction was subjected to GC-MS using an Agilent $6890 \mathrm{~N}$ Network GC system/5975 Inert $\times \mathrm{L}$ Mass selective Detector at $70 \mathrm{eV}$ and $20^{\circ} \mathrm{C}$. The GC column was a CP-S-il 8 CB LB, fused silica capillary column $(0.25 \mathrm{~mm} \times 30 \mathrm{~m}$, film thickness $0.25 \mu \mathrm{m})$. Helium was used as carrier gas at a flow rate of $1.2 \mathrm{ml} / \mathrm{min}$. The injector port was maintained at $250^{\circ} \mathrm{C}$; the oven temperature was programmed at $5^{\circ} \mathrm{C} / \mathrm{min}$ from $70^{\circ} \mathrm{C}$ to $300^{\circ}$ C. A solution of each fraction was prepared in chloroform at a concentration of $10 \%$ (wt/v). To $90 \mu \mathrm{l}$ of this solution, $10 \mu \mathrm{l}$ of trimethyl sulfonium hydroxide (TMSH) was added and $1 \mu \mathrm{l}$ of the resulting mixture was injected into the GC -MS apparatus. The constituents were identified by comparing their mass spectra data with those stored in NIST05 and Wiley237 database libraries.

Aluminium sheet pre-coated with silica gel $60 \mathrm{GF}_{254}$ (Merck) was used for thin layer chromatography (TLC). The spots were visualized under UV light (254 and 366 $\mathrm{nm}$ ) with a UV lamp model 52-58 mineralight, and sprayed with $50 \%$ aqueous solution of $\mathrm{H}_{2} \mathrm{SO}_{4}$ followed by heating at $100^{\circ} \mathrm{C}$.

IR spectra were measured with $\mathrm{KBr}$ disks using FT-IR8400 S Shimadzu spectrophotometer. EI-MS were carried out on a GCT Premier CAB109 TOF mass spectrometer. ${ }^{1} \mathrm{H}-,{ }^{13} \mathrm{C}-\mathrm{NMR}$ and 2D-NMR $\left(\mathrm{COSY}{ }^{1} \mathrm{H}_{-}{ }^{1} \mathrm{H}\right.$, HMBC and HSQC) spectra were recorded in acetone- $d_{6}$ (500 MHz for ${ }^{1} \mathrm{H}$ and $125 \mathrm{MHz}$ for ${ }^{13} \mathrm{C}$ ) on a BrückerAvance-500 MHz NMR spectrometer.

$(5 S, 6 R, 8 \mathrm{a} R)$-5-(carboxymethyl)-3,4,4a,5,6,7,8,8a-octahydro-5,6,8a-trimethylnaphthalenecarboxylic acid (1): White powder; ${ }^{13} \mathrm{C}$ NMR (100 $\left.\mathrm{MHz}, \mathrm{CDCl}_{3}+\mathrm{CD}_{3} \mathrm{OD}\right)$ : $\delta 14.9(5-\mathrm{Me}), 17.8(\mathrm{C}-4), 20.7$ (6-Me), $21.0(8 \mathrm{a}-\mathrm{Me})$, 25.3 (C-7), 27.0 (C-3), 29.4 (C-8), 35.2 (C-6), 37.5 (C- 
8a), 38.5 (C-5), 43.6 (C-1'), 44.6 (C-4a), 136.9 (C-2), 142.6 (C-1), 169.3 (1-COOH), 175.4 (C-2'); FABMS: $m / z$ $279\left([\mathrm{M}-\mathrm{H}]^{+}, 98\right), 153$ (100), 151 (44), 46 (13); HRFABMS: $m / z 279.1592$ (calcd. for $\mathrm{C}_{16} \mathrm{H}_{23} \mathrm{O}_{4}$ : 279.1596).

Methyl 3,4,5-trihydroxybenzoate (2): Colorless needles; ${ }^{13} \mathrm{C} \mathrm{NMR}\left(100 \mathrm{MHz}, \mathrm{CDCl}_{3}\right): \delta 51.7\left(\mathrm{OCH}_{3}\right), 109,8(\mathrm{C}-$ 2/C-6), 125.2 (C-1), 148.4 (C-3/C-5), 138.9 (C-4), EIMS: m/z 184 ([M] $\left.]^{+}, 99\right), 153$ (100), 125 (14), 107 (2), 79 (3); HREIMS: $m / z$ 184.0370 (calcd. for $\mathrm{C}_{8} \mathrm{H}_{8} \mathrm{O}_{5}:$ 184.0372).

Benzene-1,2,3-triol (3): White powder; ${ }^{13} \mathrm{C}$ NMR (100 $\left.\mathrm{MHz}, \mathrm{CDCl}_{3}\right): \delta 110.2$ (C-4/C-6), 124.6 (C-5), 138.5 (C2), 148.8 (C-1/C-3); EIMS: $m / z 126\left([\mathrm{M}]^{+}, 100\right), 108$ (21), 80 (24), 52 (27); HREIMS: $m / z 126.0312$ (calcd. for $\left.\mathrm{C}_{6} \mathrm{H}_{6} \mathrm{O}_{3}: 126.0317\right)$.

2,3-dihydroxypropyltriacontanoate (4): Whitish gum; ${ }^{13} \mathrm{C}$ NMR (125 MHz, $\left.\mathrm{CDCl}_{3}\right): \delta 14.2\left(\mathrm{CH}_{3}\right), 22.7-34.2$ (28 $\left.\mathrm{CH}_{2}\right), 63.4(\mathrm{C}-3), 65.2(\mathrm{C}-1), 70.3(\mathrm{C}-2), 172.3$ (COO); EIMS: $m / z 43$ (100), 57 (80), 71 (44), 83 (64), 85 (28), 97 (69), 99 (7), 111 (37), 125 (19), 127 (3), 139 (8), 141 (3), 153 (5).

\section{Microorganisms and growth conditions}

The microorganisms used in this study consisted of two Gram (+) bacteria (Enterococcus faecalis ATCC 10541 and Staphylococcus aureus ATCC 25922); six Gram (-) bacteria (Pseudomonas aeruginosa ATCC 27853, Escherichia coli ATCC 11775, Klebsiella pneumoniae ATCC13883, Salmonella typhi ATCC 6539, Proteus mirabilis and Shigella flexneri); and 10 yeasts (Candida albicans ATCC 9002, C. albicans ATCC 2091, C. albicans ATCC 24433, C. parapsilosis ATCC 22019, C. lusitaniae ATCC 200950, C. tropicalis ATCC 750, C. krusei ATCC 6258, C. guillermondi, C. glabbrata IP 35 and Cryptococcus neoformans IP 95026). The reference strains (ATCC) were obtained from American Type Culture Collection (Rockville, USA). The two clinical bacterial isolates were collected from "Centre Pasteur" (Yaoundé, Cameroon) and the two IP fungal strains were obtained from "Institute Pasteur" (Paris, France). The bacterial and fungal strains were grown at $35^{\circ} \mathrm{C}$ and maintained on nutrient agar (NA, Conda, Madrid, Spain) and Sabouraud Dextrose Agar (SDA, Conda) respectively.

\section{Antimicrobial assays}

The minimum inhibitory concentration (MIC) of the crude methanol extract, fractions and isolated compounds were determined through broth microdilution method in 96-well micro-titre plates as described by Zgoda and Porter [13]. The 96-well plates were prepared by dispensing into each well $100 \mu \mathrm{l}$ of Mueller Hinton broth for bacteria and Sabouraud Dextrose broth for yeasts. The test substances were initially prepared in
$10 \%$ ethanol/tween 80 in broth medium at $3124.8 \mu \mathrm{g} / \mathrm{ml}$ (methanol extract and fractions), $1250 \mu \mathrm{g} / \mathrm{ml}$ (isolated compounds) and $50 \mu \mathrm{g} / \mathrm{ml}$ (reference antibiotics). A volume of $100 \mu \mathrm{l}$ of each test sample was added into the first wells of the micro-titre plate. Serial two-fold dilutions of these test samples were made and $100 \mu \mathrm{l}$ of inoculum standardized at $10^{6} \mathrm{CFU} / \mathrm{ml}$ for bacteria or $2.5 \times 10^{5} \mathrm{CFU} / \mathrm{ml}$ for yeasts (at $600 \mathrm{~nm}$, Jenway 6105 UV/Vis spectrophotometer- $50 \mathrm{~Hz} / 60 \mathrm{~Hz}$ ) [14] was then added into each well. The last wells $\left(\mathrm{N}^{\circ} 12\right)$ served as sterility controls (contained broth only) or negative control (broth plus inoculum). This gave final concentration ranges of $781.25-0.76 \mu \mathrm{g} / \mathrm{ml}, 312.50-0.30 \mu \mathrm{g} / \mathrm{ml}$ and $12.50-0.01 \mu \mathrm{g} / \mathrm{ml}$ for the methanol extract or fractions, isolated compounds and reference substances respectively. The plates were sealed with parafilm, then agitated with a plate shaker to mix their contents and incubated at $35^{\circ} \mathrm{C}$ for $24 \mathrm{~h}$ for bacteria and $48 \mathrm{~h}$ for yeast.

The MICs of each test sample was detected following addition of $50 \mu \mathrm{l}(0.2 \mathrm{mg} / \mathrm{ml}) p$-iodonitrotetrazolium chloride (INT, Sigma-Aldrich, South Africa) solution for bacteria. Viable bacteria reduced the yellow dye to a pink colour. For yeast, MICs were determined by visualising the turbidity of the wells. The MIC corresponded to the lowest well concentration where no colour or turbidity change was observed, indicating no growth of microorganism. The MBC or MFC was determined by adding $50 \mu \mathrm{l}$ aliquots of the clear wells to $150 \mu \mathrm{l}$ of freshly prepared broth medium and incubating at $35{ }^{\circ} \mathrm{C}$ for $48 \mathrm{~h}$. The MBC or MFC was regarded as the lowest concentration of test sample which did not produce a colour or turbidity change as above. All tests were performed in triplicates.

\section{DPPH radical scavenging activity}

Radical scavenging activity of test samples (methanol extract, fractions and isolated compounds) was determined spectrophotometrically (Jenway, spectrophotometer model 1605) at $517 \mathrm{~nm}$ under UV/Visible light using DPPH radical [15]. The methanol extract and fractions, isolated compounds, and L-ascorbic acid were prepared in methanol and tested at concentration ranges of 200 to $6.25 \mu \mathrm{g} / \mathrm{ml}, 64$ to $0.25 \mu \mathrm{g} / \mathrm{ml}$ and 8 to $0.25 \mu \mathrm{g} /$ $\mathrm{ml}$ respectively. A volume of $900 \mu \mathrm{l}$ of DPPH solution $(20 \mathrm{mg} / \mathrm{l})$ was mixed with $100 \mu \mathrm{l}$ of test sample in a curve and the absorbance $(\mathrm{Ab})$ was read immediately and after $30 \mathrm{~min}$ incubation at room temperature (As). The experiments were carried out in triplicate. The percentages of DPPH scavenged (RSa \%) by test samples were calculated as:

$$
\operatorname{Rsa}(\%)=\frac{[\mathrm{Ab}-\mathrm{As}]}{\mathrm{Ab}} \times 100
$$


The radical scavenging activity fifty $\left(\mathrm{RSa}_{50}\right)$ corresponding to the amount of sample necessary to decrease by $50 \%$ the amount of free radical DPPH was determined by plotting the scavenging activity against the logarithm of sample concentration [16].

\section{Statistical analysis}

The data on antioxidant activity were subjected to the one-way analysis of variance (ANOVA) and results were expressed (where appropriate) as mean \pm standard deviation. Differences between means of samples were compared using Duncan's multiple range tests at $P$ $<0.05$.

\section{Results and discussion}

\section{Chemical composition and antimicrobial activity}

The qualitative analysis of the methanol extract and fractions of E. abysinica revealed the presence of alkaloids, flavonoids, tannins, saponins and cardiac glycosides (Table 1). These results show a similarity in chemical composition between Entada abyssinica and Entada africana as well as Entada phaseoloides [17]. Lipid components identified in $n$-hexane fraction were mainly saturated and unsaturated fatty acids (Table 2). The structures of the isolated compounds from E. abyssinica were established by spectroscopic analysis [IR, EIMS, $\mathrm{H}^{1}$ and $\mathrm{C}^{13} \mathrm{NMR}$ spectra in conjunction with $2 \mathrm{D}$ experiments (COSY ${ }^{1} \mathrm{H}-{ }^{1} \mathrm{H}, \mathrm{HMBC}$ and $\left.\left.\mathrm{HSQC}\right)\right]$ and direct comparison with published data. The compounds were identified as: $(5 S, 6 R, 8 \mathrm{a} R)-5$-(carboxymethyl)$3,4,4 a, 5,6,7,8,8$ a-octahydro-5,6,8a-trimethylnaphthalenecarboxylic acid (1) [18]; methyl 3,4,5-trihydroxybenzoate (methyl gallate) (2) [19]; benzene-1,2,3-triol (pyrogallol) (3) [20] and 2,3-dihydroxypropyltriacontanoate (4) (Figure 1).

The results of the antibacterial and antifungal activities of the methanol extract, fractions and isolated compounds are reported in Table 3. These substances displayed varied antibacterial and antifungal activities across the studied pathogens. The observed wide range of antimicrobial properties for the methanol extract and fractions can be explained by the presence of various groups of potentially active classes of secondary metabolites (Table 1). Indeed flavonoids [21], saponins [22], polyphenols [23], cardiac glycosides [24], coumarines [25], tannins [26], triterpenes and alkaloids [27,28] have been reported to possess antimicrobial activities. It was noted that the bacterial agents were more susceptible to the tested samples than yeasts. Yeasts like other fungi are eukaryotic organism with more complex structural organisation compared to the simple prokaryotic bacterial cells. This probably explains the difference in sensitivity of these two groups of microorganisms. According to the classification of Rios and Rico [29], the methanol extract and fractions (MIC range of 24.4 to $781.2 \mu \mathrm{g} /$ $\mathrm{ml}$ ) could be considered to possess significant (MIC < $100 \mu \mathrm{g} / \mathrm{ml})$, moderate $(100<\mathrm{MIC}=625 \mu \mathrm{g} / \mathrm{ml})$ or weak (MIC > $625 \mu \mathrm{g} / \mathrm{ml}$ ) activity against the corresponding pathogens. The antibacterial activity of the methanol extract of $E$. abysinica stem bark reported in this study are generally high compared to that of Fabry et al. [30]. The $n$-hexane fraction acted most on bacteria. Its major component, octadecenoic acid, has been reported to possess antibacterial and antifungal activities [31]. Moreover, this does not exclude the fact that the observed antibacterial activity could be a result of the combined effect of all the detected lipid components in the $n$-hexane fraction [32]. The antibacterial mechanism of action of fatty acids is still poorly understood, however, the prime target of these compounds is the cell membrane, where they interfere with the electron transport chain and oxidative phosphorylation [33]. The ethyl acetate and $n$-butanol fractions were generally more effective on both bacteria and yeasts, while the aqueous residue fraction displayed greater activity on yeasts.

Table 1 Phytochemical screening of E. abyssinica methanol extract and fractions

\begin{tabular}{llllll}
\hline $\begin{array}{l}\text { Groups of chemical } \\
\text { constituents }\end{array}$ & $\begin{array}{l}\text { Methanol } \\
\text { extract }\end{array}$ & $\begin{array}{l}n \text {-hexane } \\
\text { fraction }\end{array}$ & $\begin{array}{l}\text { Ethyl acetate } \\
\text { fraction }\end{array}$ & $\begin{array}{l}n \text {-butanol } \\
\text { fraction }\end{array}$ & $\begin{array}{l}\text { Aqueous residue } \\
\text { fraction }\end{array}$ \\
\hline Alkaloids & + & + & + & + & + \\
Flavonoids & + & + & + & + & + \\
Coumarins & + & - & + & + & + \\
Phenols & + & - & + & + & + \\
Tannins & + & - & + & - & + \\
Saponins & + & - & - & + & + \\
Steroids & - & - & + & - & - \\
Chalcones & + & - & + & + & + \\
Terpernoids & + & - & - & \\
Cardiac glycosides & + & - & & \\
\hline
\end{tabular}

+: presence; -: absence. 
Table 2 Percentage composition of chemical constituents in $\boldsymbol{n}$-hexane fraction of E.abyssinica stem bark

\begin{tabular}{|c|c|c|}
\hline Chemical constituents/Molecular ion $(\mathrm{m} / \mathrm{z})$ & Chemical structure & $\%$ \\
\hline $\begin{array}{l}\text { Hexadecanoic acid } \\
\left(\mathrm{C}_{16} \mathrm{H}_{32} \mathrm{O}_{2}\right)\end{array}$ & $\mathrm{CH}_{3}-\mathrm{CH}_{2}-\left[\mathrm{CH}_{2}\right]_{12}-\mathrm{CH}_{2}-\mathrm{COOH}$ & 17.86 \\
\hline $\begin{array}{l}9,12 \text {-Octadecadienoic acid }(\mathrm{Z}, \mathrm{Z}) \\
\left(\mathrm{C}_{18} \mathrm{H}_{32} \mathrm{O}_{2}\right)\end{array}$ & $\begin{array}{l}\mathrm{CH}_{3}-\left[\mathrm{CH}_{2}\right]_{4}-\mathrm{CH}=\mathrm{CH}-\mathrm{CH}_{2}-\mathrm{CH}=\mathrm{CH}-\left[\mathrm{CH}_{2}\right]_{7-}^{-} \\
\mathrm{COOH}\end{array}$ & 21.14 \\
\hline $\begin{array}{l}\text { 9-Octadecenoic acid (Z) } \\
\left(\mathrm{C}_{18} \mathrm{H}_{34} \mathrm{O}_{2}\right)\end{array}$ & $\mathrm{CH}_{3}-\left[\mathrm{CH}_{2}\right]_{6}-\mathrm{CH}_{2}-\mathrm{CH}=\mathrm{CH}-\left[\mathrm{CH}_{2}\right]_{7}-\mathrm{COOH}$ & 27.78 \\
\hline $\begin{array}{l}\text { Octadecanoic acid } \\
\left(\mathrm{C}_{18} \mathrm{H}_{36} \mathrm{O}_{2}\right)\end{array}$ & $\mathrm{CH}_{3}-\mathrm{CH}_{2}-\left[\mathrm{CH}_{2}\right]_{4}-\mathrm{CH}_{2}-\mathrm{COOH}$ & 2.92 \\
\hline $298(M+1), 257(5), 189(26), 121(30), 107(60), 95(100), 81(54), 55(71), 41(46), 29(10)$ & nd & 4.27 \\
\hline $327(\mathrm{M}+1), 290(2), 274(7), 189(31), 175(16), 120(63), 107(74), 95(100), 55(48), 41(46)$ & nd & 8.50 \\
\hline $\begin{array}{l}\text { 347(M+ 1), 330(77), 315(30), 256(15), 203(36), 175(49), 139(100), 119(57), 107(75), 95(82), 79(64), } 55 \\
(68), 41(55)\end{array}$ & nd & 17.50 \\
\hline Total & & 99.97 \\
\hline
\end{tabular}

nd: not determined.

The isolated compounds were equally more active on bacteria than yeasts. Compounds 2 and 3 showed greater activity $(\mathrm{MIC}=9.7-312.5 \mu \mathrm{g} / \mathrm{ml})$ than compounds $\mathbf{1}$ $(\mathrm{MIC}=39.0-312.5 \mu \mathrm{g} / \mathrm{ml})$ and $4(78.12-312.5 \mu \mathrm{g} / \mathrm{ml})$. To the best of our knowledge, the antimicrobial and antioxidant activities of compound $\mathbf{1}$ are reported herein for the first time. The presence of methyl groups on the carbon rings of this compound could be critical for its activity [34]. Compound $\mathbf{2}$ is a known medicinally important substance that was previously isolated from Entada africana [35], Acer ginnala [36] and Galla rhois, and has been reported to possess antimicrobial activities [37] and antiasthmatic effects [38]. The activities of this compound herein reported corroborates those of Jang-Gi et al. [37]

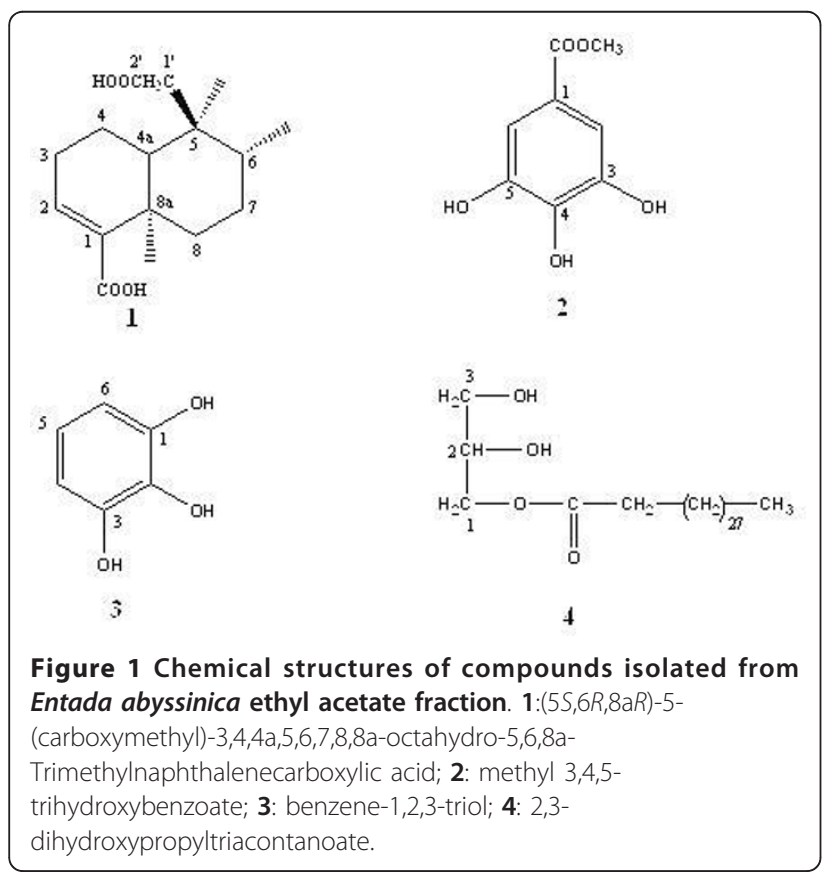

with MICs of 250 and $500 \mu \mathrm{g} / \mathrm{ml}$ on resistant bacterial strains. Compound 3 (pyrogallol) was as well active on both bacteria (MIC of 9.7 to $78.1 \mu \mathrm{g} / \mathrm{ml}$ ) and yeasts (MIC of 78.1 to $156.2 \mu \mathrm{g} / \mathrm{ml}$ ), this antimicrobial activity was found to be greater in comparison to that reported by Jin et al. [20]. Pyrogallol contains both phenolic hydroxyl groups and a system of delocalized electrons, conditions critical for its antimicrobial activity [20]. The presence of hydroxyl groups on compounds $\mathbf{2}$ and $\mathbf{3}$ could be responsible for the observed antimicrobial activity. Compound $\mathbf{4}$ recorded weak and selective antimicrobial activities against the tested microorganisms and these activities could be due to the 2,3-dihydroxypropyl moiety [39].

\section{Antioxidant activity}

The free radical scavenging activities of samples $\left(\mathrm{RSa}_{50}\right)$ are reported in Table 4. The ethyl acetate fraction $\left(\mathrm{RSa}_{50}\right.$ of $\left.3.07 \mu \mathrm{g} / \mathrm{ml}\right)$ showed the greatest activity while the $n$-hexane fraction had the least $\left(\mathrm{RSa}_{50}\right.$ of $35.87 \mu \mathrm{g} / \mathrm{ml})$. Phenols, flavonoids, saponins and tannins identified in the extract and fractions may be responsible for the observed antioxidant activities [40]. Compounds 2, 3 (phenolic compounds) and $\mathbf{4}$ (fatty ester) demonstrated interesting radical scavenging activities $\left(\mathrm{RSa}_{50}\right.$ of $1.45,1.45$ and $1.60 \mu \mathrm{g} / \mathrm{ml}$ respectively. The antioxidative effects of phenolic compounds ( 2 and 3 ) are mainly due to their redox properties, which can play an important role in absorbing and neutralizing free radicals, quenching singlet and triplet oxygen, or decomposing peroxides [40]. It is known that the antioxidant activity of an aromatic compound is proportional to the number of hydroxyl groups it contains [41]. This probably explains the high radical scavenging activities of compounds 2 and 3 . The activity of $\mathbf{2}$ in this assay was higher than that $\left(\mathrm{RSa}_{50}=2.8\right.$ $\mu \mathrm{g} / \mathrm{ml}$ ) reported by Seong et al. [37] against DPPH free radical. 
Table 3 Minimal inhibitory concentration (MIC)/minimum bactericidal or fungicidal concentration (MBC or MFC) of test substances $(\mu \mathrm{g} / \mathrm{ml})$

\begin{tabular}{|c|c|c|c|c|c|c|c|c|c|c|c|}
\hline \multirow[t]{2}{*}{ Microorganisms } & \multirow[t]{2}{*}{ Parameters } & \multicolumn{10}{|c|}{ Test samples $^{a}$} \\
\hline & & ME & $\mathrm{HF}$ & $\mathrm{EF}$ & $n \mathrm{~B}$ & AR & 1 & 2 & 3 & 4 & Ref \\
\hline \multicolumn{12}{|l|}{ Gram (-) bacteria } \\
\hline Pseudomonas & MIC & 195.3 & 24.4 & 781.2 & 390.6 & 781.2 & 39.0 & 9.7 & 9.7 & 312.5 & 1.5 \\
\hline aeruginosa & $M B C$ & 781.2 & 390.6 & $n a^{b}$ & na & na & 156.2 & 19.5 & 9.7 & $>312.5$ & 12.5 \\
\hline Proteus & MIC & 195.3 & 390.6 & 390.6 & 781.2 & na & 156.2 & 19.5 & 39.0 & na & 0.3 \\
\hline mirabilis & $M B C$ & 781.2 & na & 390.6 & na & na & 156.2 & 39.0 & 156.2 & na & 1.5 \\
\hline \multirow[t]{2}{*}{ Shigella flexneri } & $\mathrm{MIC}$ & 781.2 & 48.8 & 390.6 & 24.4 & 390.6 & 78.1 & 39.0 & 39.0 & na & 0.2 \\
\hline & $M B C$ & na & 390.6 & 390.6 & 195.3 & na & 156.2 & 156.2 & 78.1 & na & 6.2 \\
\hline Klebsiella & $\mathrm{MIC}$ & 781.2 & 24.4 & 97.6 & 781.2 & na & 78.1 & 19.5 & 78.1 & na & 0.2 \\
\hline pneumoniae & $\mathrm{MBC}$ & na & 195.3 & 390.6 & na & na & 156.2 & 39.0 & 156.2 & na & 3.1 \\
\hline \multirow[t]{2}{*}{ Salmonella typhi } & $\mathrm{MIC}$ & 781.2 & 390.6 & 97.6 & 781.2 & na & 156.2 & 39.0 & 78.1 & na & 0.3 \\
\hline & $\mathrm{MBC}$ & na & na & 390.6 & na & na & 312.5 & 156.2 & 156.2 & na & 1.5 \\
\hline \multirow[t]{2}{*}{ Escherichia coli } & $\mathrm{MIC}$ & 781.2 & 24.4 & 97.6 & 24.4 & na & 78.1 & 39.0 & 156.2 & 312.5 & 0.2 \\
\hline & $M B C$ & na & 390.6 & 390.6 & 390.6 & na & 312.5 & 312.5 & 156.2 & $>312.5$ & 1.5 \\
\hline \multicolumn{12}{|l|}{ Gram (+) bacteria } \\
\hline Enterococcus & MIC & 195.3 & 390.6 & 390.6 & 781.2 & na & 78.1 & 39.0 & 78.1 & na & 0.2 \\
\hline faecalis & $\mathrm{MBC}$ & na & 781.2 & 781.2 & na & na & 312.5 & 312.5 & 156.2 & na & 1.5 \\
\hline Staphylococcus & $\mathrm{MIC}$ & 390.6 & 195.3 & 97.6 & 781.2 & 390.6 & 78.1 & 39.0 & 78.1 & na & 1.5 \\
\hline aureus & $M B C$ & na & na & 390.6 & na & na & 39.0 & 156.2 & 156.2 & na & 12.0 \\
\hline \multicolumn{12}{|l|}{ Yeast } \\
\hline C. albicans & $\mathrm{MIC}$ & na & na & 195.2 & 390.6 & 195.3 & 312.5 & 312.5 & 78.1 & na & 0.01 \\
\hline ATCC 2091 & MFC & na & na & 195.3 & 390.6 & 1953 & 312.5 & 312.5 & 156.2 & na & 0.08 \\
\hline C. albicans & MIC & 781.2 & 781.2 & 195.3 & 195.3 & 195.3 & 312.5 & 156.2 & 156.2 & 312.2 & 0.01 \\
\hline ATCC9002 & MFC & na & na & 781.2 & 195.3 & 390.6 & 312.5 & 156.2 & 156.2 & $>312.5$ & 0.08 \\
\hline C. albicans & $\mathrm{MIC}$ & 195.3 & 390.6 & 195.3 & 390.6 & 195.3 & 156.2 & 312.5 & 78.1 & na & 0.02 \\
\hline ATCC 24433 & MFC & 781.2 & na & 195.3 & na & 195.3 & 312.5 & 312.5 & 156.2 & na & 0.02 \\
\hline Candida & $\mathrm{MIC}$ & 781.2 & 781.2 & 195.3 & 390.6 & 390.6 & 312.5 & 156.2 & 78.1 & na & 0.01 \\
\hline parapsilosis & MFC & na & 390.6 & 781.2 & 390.6 & 781.2 & 312.5 & 156.2 & 156.2 & na & 0.08 \\
\hline Candida & $\mathrm{MIC}$ & 195.3 & na & 48.8 & 390.6 & 195.3 & 312.5 & 312.5 & 78.1 & na & 0.04 \\
\hline tropicalis & MFC & 781.2 & na & 390.6 & 781.2 & 195.3 & 312.5 & 312.5 & 156.2 & na & 0.08 \\
\hline \multirow[t]{2}{*}{ Candida krusei } & $\mathrm{MIC}$ & na & 781.2 & 781.2 & 390.6 & 195.3 & 312.5 & 312.5 & 78.1 & na & 0.04 \\
\hline & MFC & na & na & na & 390.6 & 195.3 & 312.5 & 312.5 & 156.2 & na & 0.04 \\
\hline \multirow[t]{2}{*}{ Candida glabrata } & $\mathrm{MIC}$ & na & 781.2 & 195.3 & 390.6 & 390.6 & 78.1 & 312.5 & 78.1 & na & 0.02 \\
\hline & MFC & na & na & 195.3 & na & 781.2 & 78.1 & 312.5 & 156.2 & na & 0.02 \\
\hline Candida & MIC & 781.2 & 390.6 & 195.3 & 195.3 & 195.3 & 156.2 & 312.5 & 78.1 & na & 0.01 \\
\hline lusitaniae & MFC & na & 781.2 & 390.6 & 195.3 & 195.3 & 156.2 & 312.5 & 78.1 & na & 0.08 \\
\hline Cryptococcus & $\mathrm{MIC}$ & 390.6 & 781.2 & 97.6 & 390.6 & 195.3 & 195.3 & 78.1 & 78.1 & na & 1.00 \\
\hline neoformans & MFC & na & na & 781.2 & 390.6 & 195.3 & 312.5 & 156.2 & 78.1 & na & 1.00 \\
\hline Candida & $\mathrm{MIC}$ & 781.2 & 781.2 & 195.3 & 390.6 & 390.6 & 312.5 & 156.2 & 78.1 & na & 0.01 \\
\hline guillermondi & MFC & na & na & na & na & 781.2 & 312.5 & 156.2 & 156.2 & na & 0.08 \\
\hline
\end{tabular}

${ }^{a}$ ME: methanol extract; HF: $n$-hexane fraction; EF: Ethyl acetate fraction; $n B: n$-butanol fraction; AR: Aqueous residue; $1:(5 S, 6 R, 8 a R)-5-($ carboxymethyl)3,4,4a,5,6,7,8,8a-octahydro-5,6,8a-Trimethylnaphthalenecarboxylic acid; 2: methyl 3,4,5-trihydroxybenzoate; 3: benzene-1,2,3-triol; 4: 2,3dihydroxypropyltriacontanoate and Ref (reference drugs): ciprofloxacin for bacteria and nystatin for yeasts.

${ }^{b}$ na: not active at concentrations upto $781.2 \mu \mathrm{g} / \mathrm{ml}$. 


\section{Table 4 Test sample's concentration reducing $50 \%$ of free radical DPPH $\left(\mathrm{RSa}_{50}\right)$}

\begin{tabular}{lc}
\hline Test samples & $\mathrm{RSa}_{\mathbf{5 0}}(\boldsymbol{\mu g} / \mathrm{ml})$ \\
\hline Plant extract and fractions & \\
Methanol extract & $7.12 \pm 0.21^{*}$ \\
$n$-hexane fraction & $35.87 \pm 0.07^{*}$ \\
Ethyl acetate fraction & $3.07 \pm 0.04^{*}$ \\
$n$-butanol fraction & $3.10 \pm 0.10^{*}$ \\
Aqueous residue fraction & $7.15 \pm 0.08^{*}$ \\
Isolated compounds & \\
$\mathbf{1}$ & $298 \pm 0.57^{*}$ \\
$\mathbf{2}$ & $1.45 \pm 0.00^{*}$ \\
$\mathbf{3}$ & $1.45 \pm 0.00^{*}$ \\
$\mathbf{4}$ & $1.60 \pm 0.01^{*}$ \\
Reference substance & \\
L-ascorbic acid & $0.68 \pm 0.00$ \\
\hline
\end{tabular}

${ }^{a}$ 1:(5S,6R,8aR)-5-(carboxymethyl)-3,4,4a,5,6,7,8,8a-octahydro-5,6,8aTrimethylnaphthalenecarboxylic acid; 2: methyl 3,4,5-trihydroxybenzoate; 3 : benzene-1,2,3-triol and 4: 2,3-dihydroxypropyltriacontanoate.

*Scavenging activity significantly lower than the reference, Duncan $(p<0.05)$.

\section{Conclusion}

The results obtained from this study reveal that the stem bark of $E$. abyssinica may be useful in the development of an antimicrobial phytomedicine which can be standardised using the isolated compounds.

\section{Author details}

${ }^{1}$ Laboratory of Microbiology and Antimicrobial Substances, Faculty of Science, University of Dschang, P.O. Box 67 Dschang, Cameroon. ${ }^{2}$ Department of Chemistry, Faculty of Science, University of Dschang, P.O. Box 67, Dschang, Cameroon. ${ }^{3}$ Laboratoire de Chimie Agro-Industrielle - UMR 1010 INRA/INP-ENSIACET 4, Allée Emile Monso 31432 Toulouse Cedex 4, France. ${ }^{4}$ Graduate School of Pharmaceutical Sciences, Tohoku University, 6-3 Aoba, Aramaki, Aoba-ku, Sendai 980-8578, Japan.

\section{Authors' contributions}

GNT and PKL carried out the assays in this study; HKP participated to extract fractionation and isolation of compounds; $\mathrm{HK}$ and $\mathrm{YO}$ participated to structural elucidation of compounds $\mathbf{1}$ and $\mathbf{2} ; \mathrm{GV}$ and GG YO participated to structural elucidation of compounds $\mathbf{3}$ and $\mathbf{4}$; JRK designed and supervised the work along with the manuscript writing. All authors read and approved the final manuscript.

\section{Competing interests}

The authors declare that they have no competing interests.

Received: 24 May 2011 Accepted: 19 July 2011 Published: 19 July 2011

\section{References}

1. Cowan MM: Plant products as antimicrobial agents. Clinical Microbiology Reviews 1999, 12:564-582

2. Jain $P$, Bansal $D$, Bhasin $P$, Anjali : Antimicrobial activity and phytochemical screening of five wild plants against Escherichia coli, Bacillus subtilis and Staphylococcus aureus. Journal of Pharmaceutical Research 2010, 3:1260-1262.

3. Kamlesh $D$, Yogesh $S$, Ajit P: Evaluation of in vitro antioxidant activity of Sida rhombifolia (L.) Ssp. retusa (L.). Journal of Medicinal Food 2007, 10:683-688.

4. Katende $A B$ : Useful trees and shrubs for Uganda. Identification, Propagation and Management for Agricultural and Pastoral
Communities. Regional Soil Conservation Unit (RSCU), Swedish International Development Authority (SIDA) 1995.

5. Bekele-Tesemma A, Birnie A, Tengnas B: Useful trees and shrubs for Ethiopia. Regional Soil Conservation Unit (RSCU), Swedish International Development Authority (SIDA) 1993.

6. Haile Y, Delenasaw Y: Traditional medicinal plant knowledge and use by local healers in Sekoru District, Jimma Zone, Southwestern Ethiopia. Journal of Ethnobiology and Ethnomedicine 2007, 3:24.

7. Cos P, Hermans N, De Bruyne T, Apers S, Sindambiwe JB, Witvrouw M, De Clercq E, Vanden Berghe D, Pieters L, Vlietinck AJ: Antiviral activity of Rwandan medicinal plants against human immunodeficiency virus type1 (HIV-1). Phytomedicine 2002, 9:62-68.

8. Fabry W, Paul O, Rainer A: Antibacterial activity of East African medicinal. Journal of Ethnopharmacology 1998, 60:79-84.

9. Freiburghaus AF, Steck HP, Brun R: Bioassay-guided isolation of a diastereoisomer of kolavenol from Entada abyssinica active on Trypanosoma brucei rhodesiense. Journal of Ethnopharmacology 1998, 61:179-183.

10. Asfaw D, Olaf K, Martin GS, Günter M, Franz B, Dawit A, Ernst H: A diterpene, a flavonoid glycoside and a phytosterol from Entada abyssinica stem bark. Monatshefte Chemie 2000, 131:401-408.

11. Nyasse B, Ngantchou I, Tchana EM, Sonké B, Denier C, Fontaine C: Inhibition of both Trypanosoma brucei bloodstream form and related glycolytic enzymes by a new kolavic acid derivative isolated from Entada abyssinica. Pharmazie 2004, 59:873-875.

12. Sofowara A: Medicinal plants and traditional medicine in Africa Ibadan, Nigeria, Spectrum books Ltd; 1993.

13. Zgoda JR, Porter JR: A convenient microdilution method for screening natural products against bacteria and fungi. Pharmaceutical Biology 2001, 39:221-225

14. Tereschuk ML, Riera MVQ, Castro GR, Abdala LR: Antimicrobial activity of flavonoid from leaves of Tagetes minuta. Journal of Ethnopharmacology 1997, 56:227-232.

15. El-Ghorab A, Mahgoub M, Bekheta M: Effect of some bioregulators on the chemical composition of essential oil and its antioxidant activity of Egyptian carnation (Dianthus caryophyllus). Journal of Essential Oil Bearing Plants 2006, 9:214-222.

16. Yassa N, Razavi BH, Hadjiakhoondi A: Free radical scavenging and lipid peroxidation activity of the shahani black grape. Pakistan Journal of Biological Science 2008, 11:2513-2516.

17. Tibiri A, Richard WS, Noufou O: Evaluation of antioxidant activity, total phenolic and flavonoid contents of Entada africana Guill. et Perr. (Mimosaceae) organ extracts. Research Journal of Medical Sciences 2010, 4:81-87.

18. Aquino R, Ciavatta ML, De Tommasi N, Gacs-Baitz E: Tetranorditerpenes from Detarium microcarpum. Phytochemistry 1992, 31:1823-1825.

19. Seon WH, Jun L, Hyun SK, Kyung DL, Sang HN, Ki HP, Min SY: Comparison of tyrosinase inhibitory effect of the natural antioxidants from Cedrela sinensis. Agricultural and Chemical Biotechnologies 2005, 48:144-147.

20. Jin AL, In KO, II SY, Seung HB: Antimicrobial activity of phenolic compounds against skin inflammation microorganisms. Journal of Cosmetics and Public Health 2005, 1:1-5.

21. Fairouz M, Amar Z, Narimane S, Ahmed T, Salah R: Flavonoid constituents from Algerian launaea resedifolia (O.K.) and their antimicrobial activity. Records of Natural Products 2010, 4:91-95.

22. Pavithra PS, Janani VS, Charumathi KH, Indumathy R, Potala S, Verma RS: Antibacterial activity of plants used in Indian herbal medicine. International Journal of Green Pharmacy 2010, 4:22-28.

23. Okoro IO, Auguster O, Edith OA: Antioxidant and antimicrobial activities of polyphenols from ethnomedicinal plants of Nigeria. African Journal of Biotechnology 2010, 9:2989-2993.

24. Ebana RUB, Madunagu BE, Ekpe ED, Otung IN: Microbiological exploitation of cardiac glycosides and alkaloids from Garcinia kola, Boreria ocymoides, Kola nitida and Citrus aurantifolia. Journal of Applied Bacteriology 1991, 71:398-401.

25. Aziz B, Kozeta V, Islam K: Antibacterial activity of coumarin derivatives synthesized from hydroxy-4-2H-[1]-Benzopyran-2-one. The comparison with standard drug. Journal of Internet Environmental Application \& Science 2010, 5:247-252.

26. Selime MÇ, Binnur MY, Ali NY: Determination of antimicrobial activity of tannic acid in pickling process. Romanian Biotechnological Letters 2010, 15:5325-5330. 
27. Faizi S, Khan RA, Azher $S$, Khan SA, Taussef $S$, Ahmad A: New antimicrobial alkaloids from the roots of Polyalthia longifolia var. pendula. Planta Medica 2003, 69:350-355.

28. Gonzaga WA, Weber AD, Glacomeli SR, Dalcol II, Hoelzel SC, Morel AF: Antibacterial alkaloids from Zanthoxylum rhoifolium. Planta Medica 69:371-374.

29. Rios JL, Recio MC: Medicinal plants and antimicrobial activity. Journal of Ethnopharmacology 2005, 100:80-84.

30. Ching TH: New bioactive fatty acids. Asia Pacific Journal of Clinical Nutrition 2008, 17:192-195.

31. Zhao J, Shan T, Huang Y, Liu X, Gao X, Wang M, Jiang W, Zhou L: Chemical composition and in vitro antimicrobial activity of the volatile oils from Gliomastix murorum and Pichia guilliermondii, two endophytic fungi in Paris polyphylla var. yunnanensis. Natural Products Communication 2009, 4:1491-1496.

32. Desbois AP, Smith VJ: Antibacterial free fatty acids: activities, mechanisms of action and biotechnological potential. Applied Microbiology and Biotechnology 2010, 85:1629-1642.

33. Subbanwad GR, Baseer MA, Vibhute YB: Synthesis and antimicrobial activity of some new isoxazolines and 1,5-benzothiazepines. Indian Journal of Pharmaceutical Sciences 2002, 64:264-266.

34. Cioffi G, D'auria M, Braca A, Mendez J, Castillo A, Morelli I, De Simone F, De Tommasi N: Antioxidant and free-radical scavenging activity of constituents of the leaves of Tachigalia paniculata. Journal of Natural Products 2002, 65:1526-1529.

35. Seong $\mathrm{SH}$, Seog CL, Yong WC, Jin HK, Seung HB: Antioxidant activity of crude extract and pure compounds of Acer ginnala Max. Bulletin of Korean Chemical Society 2004, 25:389-3891.

36. Jang-Gi C, OK-Hwa K, Young-Seob L, You-Chang O, Hee-Sung C, Hye-Jin J, Dong-Won S, Dong-Yeul K: Antibacterial activity of methyl gallate isolated from Galla rhois or carvacrol combined with nalidixic acid against nalidixic acid resistant bacteria. Molecules 2009, 14:1773-1780.

37. Rohini C, Deshpande VH, Deshpande NR: Methyl gallate, the medicinally important compound: A review. Electronic Journal of Environmental, Agricultural Food and Chemistry 2005, 4:956-962.

38. Weiguang Z, Emily E, Brendon C, Lara G, David CJ: Structural requirement for the agonist activity of the TLR2 ligand Pam2Cys. Biomedical and Life Sciences 2010, 39:471-480.

39. Yasukazu O, Takuma S: Antioxidant and photo-antioxidant activities of chalcone derivatives. Journal of the Japan Petroleum Institute 2008, 51:298-308.

40. Osawa T: Novel natural antioxidants for utilization in food and biological systems. In Post Harvest Biochemistry of Plant Food-materials in the Tropics. Edited by: Garcia I, Mendoza, V. Uritani. Scientific Societies Press, Japan; 1994:241-251.

41. Simić A, MManojlović D, Šegan D, Todorović M: Electrochemical behavior and antioxidant and prooxidant activity of natural phenolics. Molecules 2007, 12:2327-2340.

\section{Pre-publication history}

The pre-publication history for this paper can be accessed here: http://www.biomedcentral.com/1472-6882/11/57/prepub

doi:10.1186/1472-6882-11-57

Cite this article as: Teke et al:: Antimicrobial and antioxidant properties of methanol extract, fractions and compounds from the stem bark of Entada abyssinica Stend ex A. Satabie. BMC Complementary and Alternative Medicine 2011 11:57.

\section{Submit your next manuscript to BioMed Central and take full advantage of:}

- Convenient online submission

- Thorough peer review

- No space constraints or color figure charges

- Immediate publication on acceptance

- Inclusion in PubMed, CAS, Scopus and Google Scholar

- Research which is freely available for redistribution

Submit your manuscript at www.biomedcentral.com/submit
Biomed Central 